\title{
From Emerging to Connected E-Government: The Effects of Socioeconomics and Internal Administration Characteristics
}

Luis Rodríguez-Domínguez. University of Salamanca. Spain. 1rodomin@usal.es

Isabel María García Sánchez. University of Salamanca. Spain. lajefa@usal.es

Isabel Gallego Álvarez. University of Salamanca. Spain. igallego@usal.es

\begin{abstract}
The aim of this study is to explain the development of e-government using a new measure of the content, presentation, navigability and interaction of the websites created by public administrations as illustrated in the United Nations 2008 report, Services Delivery by Stages. The se results differ from previous empirical analyses, showing that citizens' economic and education levels are not the main factors driving the development of digital administration. On the contrary, the sophisticated design of e-government seems to be linked strongly to the idea of a new public management defined by organizations such as OECD, as well as a North American style of economic development.
\end{abstract}

Keywords: e-government; services stages; internet; public administration

\section{INTRODUCTION}

The numerous advantages associated with use of the Internet as a communication channel have not gone unnoticed by politicians and public managers, who have discovered a new medium for communicating with citizens. As Wong and Welch (2004) point out, the adoption of web-based technologies in public administration has created a new government-and-citizen interface.

Several studies have analyzed how far digital administration has developed (i.e., West, 2000, 2001, 2002, 2003 and 2004; Caba et al., 2005; Torres et al., 2005; Torres et al., 2006; Christou and Simpson, 2009), while other have focused on format and volume, the quality of the budgetary and financial information 
disclosed (i.e., Laswad et al., 2005; Cárcaba and García, 2008) and factors associated with the degree of development of e-government (i.e., Siau and Long, 2006; Kim, 2007; Pina et al., 2007b; Tolbert et al., 2008; Gandía and Archidona, 2008).

In the first group of studies, the results show that most regional and local governments currently have websites, although in most cases, they are little more than governmental billboards. Furthermore, e-government initiatives are still predominantly non-interactive and non-deliberative; they tend only to reflect current service delivery patterns without transforming them.

Each of the papers that analyze the extent of e-government development focuses on different national contexts (e.g., Spain, USA, Canada, Australia, European countries). Many stress the relevance of the wealth levels, institutional capacity and political participation.

However, these studies demonstrate that there is a common limitation that is a consequence of the fact that the items analysed on the websites of the different administrations relate to the content, presentation and navigability of the main website, without taking into consideration that the different administrations are configured from an existing set of Ministries or City Halls; these offices control specific areas, such as finance, health and education, and together, they constitute the government in an overall sense.

Moreover, these studies focus on information disclosure features and their formats, ignoring the concept that e-government must be understood as more than a simple tool for reporting public activities. Rather, e-government should facilitate the two-way interaction between citizens and their governments, with the goal of encouraging citizen participation in public management and the political process.

In this sense, the current study aimed to overcome these indicated limitations by considering the level of development of the websites of 192 countries worldwide and the percentage of national administration services that show an emerging, enhanced, interactive, transactional or connected stage of development. This information has been gathered from the United Nations Organizations report on e-government, Services Delivery by Stages 2008.

Next, we examined which factors have determined the development of egovernment through dependency models based on Tobit regressions for selected 
dependent variables. Such determinants can be grouped into (1) socioeconomic and demographic factors, that is, the level of economic and technological development and education of citizens, and (2) internal features of the public institutions, such as organizational complexity of the public entity, availability of financial resources, degree of leverage, efficacy, the style of public management and the level of corruption control.

According to Gandía and Archidona (2008), analyzing these factors allows us to identify these institutions' deficiencies in order to offer suggestions for improving website development. The results show that the development of egovernment is strongly associated with management effectiveness in the central administration, as well as with the reformist style of public administration promoted by the OECD.

Both the American and Middle Eastern styles of economic development and technological development have a significant direct relationship with the configuration of public websites as sophisticated systems of interaction between government and citizens. Countries with the highest indexes of corruption, meanwhile, develop e-government systems focused on information disclosure.

\section{THE EVOLUTION OF E-GOVERNMENT}

Electronic government is based on an agency relationship in which the voter is the principal and the public manager plays the role of agent (Banker and Patton, 1987). In this relationship, it is assumed that politicians will attempt to satisfy their own interests, mainly their re-election, and advance in their political or professional careers and increase their current and future incomes. Voters' wealth depends on the agents' actions and, consequently, each voter has incentives to monitor politicians' behavior (Zimmerman, 1977). These agency relationships provide public managers with incentives to disclose information voluntarily, allowing their activities to be monitored.

Therefore, e-government arises as a way of increasing citizens' trust in governments and improving the valuations they make about political management (Tolbert and Mossberger, 2006). In this sense, e-government is expected to play a critical role in public administration and governance in the future; thus, it will assist in the innovation of governance processes and improved efficiency and effectiveness while also providing more participative opportunities for citizens 
(Lee, 2010). Its objective is focused on bringing public administration closer to citizens and on restoring trust in governments (Torres et al., 2005).

The Internet has many advantages, including time flexibility without the need for movement, as well as a lower cost as compared with traditional systems of relationships between citizens and administration. Thus, it is an optimal mechanism for interaction between both parties.

Similarly, e-government can be considered to be 'any way information technology is used to simplify and improve transactions between governments and other actors such as constituents, businesses and other governmental agencies' (Sprecher, 2000). It involves a set of technological processes that attempt to change both the delivery of public services and the wider scope of interactions between citizens and governments (Torres et al., 2005).

Therefore, e-government is currently considered to be not only a tool for reporting but also an effective communication channel for citizens to participate in democratic institutions and political processes (Justice et al., 2006; Siau and Long, 2006). In this way, the image of the public administration can be improved; citizens can perceive governments as accessible, transparent, responsible, effective and participatory as they increasingly use public websites to communicate and to conduct procedures and complete paperwork with them (Tolbert and Mossberger, 2006).

\section{DETERMINANTS OF THE LEVEL OF DEVELOPMENT OF E- GOVERNMENT}

Several factors, including both socioeconomic factors and the characteristics of public agencies, influence the development e-government.

\subsection{Socioeconomic factors}

The economic, technological, demographic and educational development of countries, municipalities and institutions can drive the implementation of egovernment.

\subsubsection{Wealth or economic development}

According to most of the previous studies, the development of e-government overall depends on a country's economic performance (Siau and Long, 2006); 
strong economic performance can be considered a necessary condition for egovernment to develop (Kim, 2007).

The level of economic development is directly linked to a governing body's capacity both to buy computers and technological devices and to access the Internet. Countries with a lower level of economic development may be at a notable disadvantage in the adoption and implementation of information technologies and possibilities of communicating with the public administration, owing to the insufficiency of human and financial resources.

Consequently, previous studies that have analyzed the influence of economic wealth (e.g., Christiaens, 1999; Laswad et al., 2005; Siau and Long, 2006; Kim, 2007; Tolbert et al., 2008; Serrano-Cinca et al., 2009) have usually found a positive association between the level of wealth and the use of e-government.

Taking into consideration these previous works, we proposed the following hypothesis:

H1: A direct relationship exists between a country's economic wealth and the development of e-government.

To test this hypothesis, we used the variable Gross Domestic Product per capita (GDP at purchasing power parity), which was obtained from the World Handbook 2007 and is available on the CIA website (www.cia.gov). This figure has traditionally been used in studies on e-government. Likewise, we considered five dummy variables according to the percentage of contribution of agriculture, industry and services to total GDP (AGRI, MAN, SERV, AGRISER, MANSERV), representing agriculture, manufacturing, services, agricultureservices and manufacturing-services activities, as the predominant sectors of the business activity in each country. Moreover, we included six dummy variables to represent the effect of the continents and to group the different countries analyzed (ASIA, EE -Eastern Europe-, AMERICA, WE -Western Europe-, AFRICA, ME - Middle East-).

\subsubsection{Technological development}

The implementation of e-government demands significant investments in both the technical and administrative infrastructures that allow the websites to be updated using advanced software and technologies (Kim, 2007). 
The extent of Internet use is the force behind managing e-government. Given that Public Administrations' use of the Internet can be conceived as an answer to the increasing demands of a population that uses the Internet, the extent of Internet use will determine technological development. The greater the number of people with access to the Internet, the greater the number of possible ways to use web platforms to facilitate the administration-citizen relationship (Tolbert et al., 2008). Gandía and Archidona (2008) underline the essential role played by technology and education in order to explain citizens' use of the Internet. Thus, when access to technology and education levels rise, so too does the likelihood that citizens will consult public administration websites.

Based on these studies, we developed the following hypothesis:

H2: A direct relationship exists between the level of technological development and the development of e-government.

We analyzed technological development through the variable IP (Internet Penetration) which represents the ratio of Internet per 100 users. This variable comes from the United Nations Telecommunication Infrastructure Index in 2007, and both Kim (2007) and Pina et al. (2007b) use it, as well.

\subsubsection{Education}

Education level is also a fundamental factor in the use of e-government by citizens. To access and use the Internet, individuals must have technical skills and be able to search, use, interpret and assess information (Mossberger et al., 2004; Kim, 2007). Furthermore, a well-educated and trained population will demand a higher volume of information from public administrations (Tolbert et al., 2008).

Although a significant influence of education was not found at the early stages of e-government adoption (McNeal et al., 2003), most recent studies have confirmed its importance (Kim, 2007; Gandía and Archidona, 2008; Tolbert et al., 2008). Consequently, we formulated the following hypothesis:

H3: Education levels positively influence the development of e-government.

Therefore, we used the variable Adult Literacy (AL), from the United Nations Human Capital Index in our study. Kim (2007) Gandía and Archidona (2008) among others have also studied it. 


\subsection{Features of public bodies}

Public administrations that use e-government may be influenced by certain factors that affect that government, such as organizational complexity, institutional capacity, degree of leverage and administration effectiveness.

\subsubsection{Organizational complexity of public bodies}

A priori, the development of e-government seems more justified in countries that have large-sized national administrations. In this sense, the size of the public body - or, more specifically, the population - has been taken as a measure of the level of complexity of the public administration and the government; population size can be considered to be one of the internal factors underlying the activities of the public manager (Cárcaba and García, 2008). Population can also be taken as an indicator of the overall level of a government's resources and the level of professionalization and specialization of its civil servants.

Thus, the most populated countries tend to have larger organizations and greater levels of financial and human resources. In addition, they offer incentives to adopt measures of e-government as tools to manage the practical challenges and the high costs of communicating effectively with different agents and public bodies (Justice et al., 2006).

Nevertheless, previous studies have not produced conclusive evidence about this influence. While Ingram (1984), Ingram and DeJong (1987) and Laswad et al. (2005) did not find a statistically significant association, Evans and Patton (1987) and Moon (2002) obtained evidence for a direct relationship. Recently, SerranoCinca et al. (2009) showed that size affects e-disclosure by local public administrations.

Likewise, those countries organized in federal states exhibit a greater administrative complexity, which, in turn, affects the need for developing mechanisms of coordination among them; in those contexts, e-government can constitute a suitable device for disclosing information and establishing connections between the different administrations.

Based on these theoretical arguments, we formulated the following hypothesis:

H4: A public body's complexity positively influences the development of $e$ government. 
To test this hypothesis, we used the variable SIZE, which represents the size of the public body measured by the number of inhabitants in the country. This variable is taken from the World Handbook 2007 and is available on the CIA website (www.cia.org); Gandía and Archidona (2008) have previously studied this variable.

\subsubsection{Institutional capacity}

E-government requires the building of a technical and administrative infrastructure. As such, a public body's budget may constitute an important determinant for implementing e-government practices. A budget provides a measure of the management quality, which can benefit local politicians, increasing their possibilities for re-election and reducing interest costs (Pina, Torres and Royo, 2007b).

However, Pina et al. (2007b) did not detect a statistically significant association between these factors. Similarly, when analyzing the situation in the US, Tolbert et al. (2008) found that states with higher budgetary incomes per capita are not more likely to develop digital government.

Taking into consideration these theoretical arguments, we tested the following hypothesis:

H5: Countries with higher budgets will show a higher level of e-government development.

Institutional capacity is measured by the budgetary expense per capita (BUDGET) (CIA, 2007).

\subsubsection{Degree of leverage}

Public managers are provided with incentives to reduce the cost of debt, thereby increasing the financial resources available for other programs that can enhance politicians' benefits (Zimmerman, 1977). Such incentives lead public managers to provide information for the monitoring of their activities, which in turn leads to greater use of digital government.

Whereas Baber and Sen (1984), Christiaens (1999) and Gandía and Archidona (2008) did not find a significant relationship between a public body's leverage and the disclosure of a higher volume of information online, Ingram and DeJong 
(1987), Evans and Patton (1987) and Laswad et al. (2005) did present evidence of a positive relationship.

Based on the diversity of previous results, we tested the following hypothesis:

H6: The degree of leverage of a public body positively influences the development of e-government.

The degree of leverage is measured through the public debt (DEBT) (CIA, 2007).

\subsubsection{Administration effectiveness}

The effectiveness of a public administration and the government may be a major factor behind the development of digital government. This effectiveness encompasses several issues, such as the quality of public service provided, the quality of the bureaucracy, the competence of civil servants, the independence of the civil service from political pressures and the credibility of the government's commitment to policies (Kaufman et al., 2003).

With the aim of achieving an effective electronic government, civil servants must be competent and have access to the infrastructure and technology (Kim, 2007). Government effectiveness could significantly contribute to the development of web-based government-to-citizen (G2C) services, government-tobusiness (G2B) digital procurement processes and government-to-government (G2G) connectivity (Laswad et al., 2005).

Consequently, we formulated the subsequent hypothesis:

H7: There is a significant, positive relationship between governmental effectiveness and the development of e-government.

Government effectiveness is measured by an index devised by Kaufmann, Kraay, and Mastruzzi (2008) for the World Bank (GE). This variable represents the quality of bureaucracy, budgetary and financial management, institutional effectiveness, general infrastructure, and the quality of the supply of public goods (e.g., education and basic health).

\subsubsection{Administrative culture}

According to Allen et al. (2001), the necessary change in public government can be blocked by an administrative culture that is badly adapted to the digital 
world. Rodríguez et al. (2005) and Pina et al. (2007b) underscored the strong influence of administrative culture. For instance, Nordic and Anglo-Saxon countries, which are considered to be customer-oriented, better answer their citizens' needs through e-government; on the contrary, continental European countries, which are oriented traditionally towards the fulfillment of law as the main source for legitimacy, act more slowly in incorporating new styles of public government. Even so, these countries exhibit greater development of digital administration in comparison with those countries whose governments do not focus on the improvement of public management.

When discussing administrative culture, it is worth emphasizing the role played by the OECD, which promotes public management initiatives and the use of web platforms in the name of achieving greater transparency in their member states (Caba et al., 2008).

Consequently, we formulated the following hypothesis:

H8: Public administrative style, whether oriented toward citizens or interested in processes of legitimacy, positively influences the development of e-government.

We used the variable OECD, which identifies whether the country analyzed is a member of the OECD in order to identify an administrative culture. As stated above, this body promotes the introduction of significant reforms in public administration, both to improve the effectiveness and efficiency of public management and to encourage citizens' participation.

\subsubsection{Control of corruption}

Pina et al. (2007b) affirmed that countries with the lowest levels of corruption are more transparent in the disclosure of information about the management of public funds and vice versa.

Although such studies did not find a statistically significant relationship between the two variables, Kim (2007) found a direct relationship between the control of corruption and the development of e-government. Consequently, we added this hypothesis to our study:

H9: The control of corruption positively influences the development of $e$ government. 
The extent of control of the level of corruption (CORRU) was analyzed according to the Transparency International CPI (Corruption Perceptions Indicator) Score for 2007, which is a variable that indicates the degree to which public sector corruption is perceived by business people and country analysts that ranges from 10 (highly honest) and 0 (highly corrupt).

\section{METHODOLOGY}

\subsection{Population and sample}

To achieve our research goals, we selected most of countries worldwide as our target population. We chose this population because, on one hand, fewer studies have focused exclusively on analyzing the socioeconomic determinants of egovernment development in national public administrations (Siau and Long, 2006; Kim, 2007) and on the other hand, because of the advantages derived from the consideration of different geographic contexts. This scope allowed us to overcome the limitations of previous studies that focused on specific geographic areas, such as Spanish and European municipalities (Gandía and Archidona, 2008; Pina et al., 2007a) or the American states (Tolbert et al., 2008).

The sample used includes 192 countries selected by the United Nations for the elaboration of E-Government Survey 2008. The necessary information for the creation of the proposed variables was obtained from the World Handbook 2007 and is available on the CIA website (www.cia.gov).

\subsection{Dependent variables}

The dependent variables correspond to the five stages of e-government evolution developed by the United Nations in 2008. The UN provides five measures of the level of development of e-government: Emerging, Enhanced, Interactive, Transactional and Connected.

1. Stage I - Emerging: A government's online presence is mainly comprised of a web page and/or an official website; links to ministries or departments of education, health, social welfare, labor and finance may or may not exist. Much of the information is static, and there is little interaction with citizens.

2. Stage II - Enhanced: Governments provide more information on public policy and governance. They have created links to archived information that is 
easily accessible to citizens, such as, documents, forms, reports, laws and regulations, and newsletters.

3. Stage III - Interactive: Governments deliver online services such as downloadable forms for tax payments and applications for license renewals. In addition, the beginnings of an interactive portal or website with services to enhance the convenience of citizens are evident.

4. Stage IV - Transactional: Governments begin to transform themselves by introducing two-way interactions between 'citizen and government'. This stage includes options for paying taxes, applying for ID cards, birth certificates, passports and license renewals, as well as other similar $\mathrm{G}$ to $\mathrm{C}$ interactions, and allows citizens to access these services online. All transactions are conducted online.

5. Stage V - Connected: Governments transform themselves into a connected entity that responds to the needs of its citizens by developing an integrated back office infrastructure. This stage is the most sophisticated level of online egovernment initiatives and is characterized by the following:

a) Horizontal connections (among government agencies)

b) Vertical connections (central and local government agencies)

c) Infrastructure connections (interoperability issues)

d) Connections between governments and citizens

e) Connections among stakeholders (government, private sector, academic institutions, NGOs and civil society)

This index of five stages of service is measured by the utilization of service stages, which is defined as services provided as a percentage of the maximum services in a category. Thus, each stage was represented in a single model to analyze the effect of the independent variables.

\subsection{Analysis technique}

Based on the variables we selected to test our hypotheses, we defined the following family of models [1], in which the level of development of egovernment depends on the socioeconomic and demographic characteristics of a country, as well as the internal features of a national administration. 
ServicesStages $=f($ Socioeconomics Factors,

Internal features of the national administration)

Model (1) can be estimated empirically through model (2):

SERVICESSTAGES $S_{i}=\beta_{0}+\sum^{14}{ }_{i=1} \beta_{i} S_{F}+\sum_{i=1}^{6} \rho_{i}$ IFNA $_{i}+\varepsilon$

where

$S F$ are the independent variables that identify the socioeconomic factors of each country.

IFNA are the independent variables that reflect the internal features of a national administration.

We ran five Tobit regressions, given the structure of the dependent variables. Each estimation is performed using each of the five Services Stages typologies as variables The Tobit regression was chosen based on the censored numerical dependent variable. The five Services Stages indexes refer to numerical variables measured by the percentage of services delivered by the stages (number of services in this stage divided by the total number of services). Their values range from 0 to 100. In cases in which countries show values from 0 to 100 for any of the 5 Services Stages, the dependent variable are left-censored or right-censored; in this case, the use of the selected regression typology is more appropriate.

\section{RESULTS OF THE EMPIRICAL ANALYSIS}

\subsection{Previous descriptive analysis}

Table 1 provides the correlations between the proposed variables. The dependent variable SSI (Emerging) does not show high correlations with any of the independent and control variables. However, the variable SSII (Enhanced) displays positive relationships with the variables GE (0.6323), OECD (0.5028), CORRU (0.5612) and IP (0.6107); the variable SSIII (Interactive) presents positive relationships with GE (0.7416), OECD (0.5840), CORRU (0.7014) and IP (0.7186); the variable SSIV (Transactional) displays positive relationships with the variables GE (0.7125), OECD (0.5783), CORRU (0.7256) and IP (0.6575); and SSV (Connected) presents positive relationships with the variables GE (0.6233), OECD (0.5458), CORRU (0.6198) and IP 0.6298). 


\begin{tabular}{|l|l|l|l|l|l|l|l|l|l|}
\hline & SSI & SSII & SSIII & SSIV & SSV & SIZE & GDP & AL & IP \\
\hline SSI & 1.000 & & & & & & & & \\
\hline SSII & 0.4845 & 1.000 & & & & & & & \\
\hline SSIII & 0.4866 & 0.8485 & 1.000 & & & & & & \\
\hline SSIV & 0.3158 & 0.6379 & 0.7819 & 1.000 & & & & & \\
\hline SSV & 0.3321 & 0.6384 & 0.7565 & 0.8182 & 1.000 & & & & \\
\hline SIZE & 0.1005 & 0.0989 & 0.0550 & 0.0179 & 0.0402 & 1.000 & & & \\
\hline GDP & 0.1709 & 0.2895 & 0.2776 & 0.2748 & 0.1973 & -0.0838 & 1.000 & & \\
\hline AL & 0.2882 & 0.6115 & 0.4923 & 0.3597 & 0.3941 & -0.1036 & 0.3148 & 1.000 & \\
\hline IP & 0.2907 & 0.6107 & 0.7186 & 0.6575 & 0.6298 & -0.0992 & 0.3933 & 0.5684 & 1.000 \\
\hline CORRU & 0.3334 & 0.5612 & 0.7014 & 0.7256 & 0.6198 & -0.0933 & 0.4281 & 0.4766 & 0.8601 \\
\hline AGRI & 0.0563 & -0.1364 & -0.0722 & -0.0810 & -0.0940 & -0.0215 & -0.0555 & -0.1296 & -0.1007 \\
\hline MAN & 0.0329 & -0.2025 & -0.1964 & -0.1838 & -0.2026 & 0.1634 & -0.0206 & -0.0338 & -0.2018 \\
\hline SERV & 0.1773 & 0.3512 & 0.3840 & 0.1721 & 0.2746 & 0.0695 & 0.0839 & 0.2352 & 0.3045 \\
\hline AGRISERV & -0.3847 & -0.2053 & -0.1693 & -0.0976 & -0.1335 & -0.0029 & -0.0760 & -0.2850 & -0.1385 \\
\hline MANSERV & -0.0597 & -0.0065 & -0.1262 & 0.0387 & -0.0474 & -0.0156 & -0.0046 & 0.0182 & -0.0691 \\
\hline ASIA & 0.1245 & 0.0859 & 0.0336 & 0.0555 & 0.0585 & 0.4021 & -0.0825 & -0.1458 & -0.0182 \\
\hline EE & -0.1074 & -0.0101 & -0.1702 & -0.1859 & -0.1271 & -0.0417 & -0.1057 & 0.2256 & -0.1257 \\
\hline AMERICA & 0.1079 & 0.2073 & 0.1052 & 0.0172 & 0.1351 & -0.0392 & -0.1201 & 0.1141 & -0.1022 \\
\hline WE & 0.1105 & 0.3054 & 0.4056 & 0.3556 & 0.2633 & -0.1633 & 0.4220 & 0.3730 & 0.5176 \\
\hline AFRICA & -0.2861 & -0.6251 & -0.4818 & -0.3204 & -0.3704 & -0.0732 & -0.2222 & -0.5562 & -0.3747 \\
\hline ME & -0.1562 & -0.1408 & -0.0730 & 0.0552 & -0.0383 & -0.0832 & 0.0592 & -0.0392 & -0.0754 \\
\hline OECD & 0.2458 & 0.5028 & 0.5840 & 0.5783 & 0.5458 & -0.0449 & 0.4610 & 0.4217 & 0.7135 \\
\hline BUDGET & -0.0539 & 0.0206 & 0.0399 & 0.0297 & 0.0291 & -0.0393 & 0.0137 & 0.1165 & 0.0385 \\
\hline DEBT & -0.0343 & -0.0318 & 0.0371 & 0.0774 & 0.0451 & -0.0075 & 0.0884 & -0.0214 & 0.1242 \\
\hline GE & 0.3730 & 0.6323 & 0.7416 & 0.7125 & 0.6233 & -0.0354 & 0.4301 & 0.5016 & 0.8414 \\
\hline
\end{tabular}

Table 1. Correlation matrix

\begin{tabular}{|c|c|c|c|c|c|c|c|c|c|}
\hline & CORRU & AGRI & MAN & SERV & AGRISERV & MANSERV & ASIA & EE & AMERICA \\
\hline CORRU & 1.000 & & & & & & & & \\
\hline AGRI & -0.0740 & 1.000 & & & & & & & \\
\hline IND & $\begin{array}{l}-0.1664 \\
\end{array}$ & \begin{tabular}{|l|}
-0.0314 \\
\end{tabular} & 1.000 & & & & & & \\
\hline SERV & 0.2620 & \begin{tabular}{|l|}
0.0545 \\
\end{tabular} & \begin{tabular}{|l|}
-0.5112 \\
\end{tabular} & 1.000 & & & & & \\
\hline AGRISERV & $\begin{array}{l}-0.1230 \\
\end{array}$ & \begin{tabular}{|l|}
-0.0122 \\
\end{tabular} & \begin{tabular}{|l|}
-0.0446 \\
\end{tabular} & \begin{tabular}{|l|}
-0.2246 \\
\end{tabular} & 1.000 & & & & \\
\hline MANSERV & $\begin{array}{l}-0.0671 \\
\end{array}$ & \begin{tabular}{|l|}
-0.0314 \\
\end{tabular} & \begin{tabular}{|l|}
-0.1143 \\
\end{tabular} & \begin{tabular}{|l|}
-0.5757 \\
\end{tabular} & -0.0446 & 1.000 & & & \\
\hline ASIA & 0.0087 & $\begin{array}{l}-0.0370 \\
\end{array}$ & \begin{tabular}{|l|}
-0.0526 \\
\end{tabular} & \begin{tabular}{|l|}
-0.1081 \\
\end{tabular} & -0.0525 & 0.1934 & 1.000 & & \\
\hline $\mathbf{E E}$ & -0.2329 & \begin{tabular}{|l|}
-0.0299 \\
\end{tabular} & \begin{tabular}{|l|}
-0.0124 \\
\end{tabular} & \begin{tabular}{|l|}
-0.0120 \\
\end{tabular} & -0.0425 & -0.0124 & -0.1282 & 1.000 & \\
\hline AMERICA & -0.1212 & \begin{tabular}{|l|}
-0.0459 \\
\end{tabular} & \begin{tabular}{|l|}
-0.0254 \\
\end{tabular} & \begin{tabular}{|l|l|}
0.1920 \\
\end{tabular} & -0.0652 & -0.1672 & \begin{tabular}{|l|l|}
-0.1969 \\
\end{tabular} & \begin{tabular}{|l|}
-0.1593 \\
\end{tabular} & 1.000 \\
\hline WE & 0.5024 & $\begin{array}{l}-0.0695 \\
\end{array}$ & \begin{tabular}{|l|}
-0.0768 \\
\end{tabular} & 0.0722 & -0.0987 & 0.0994 & -0.2978 & -0.2411 & -0.3702 \\
\hline AFRICA & -0.2854 & 0.1877 & \begin{tabular}{|l|l|}
0.0454 \\
\end{tabular} & \begin{tabular}{|l|}
-0.1036 \\
\end{tabular} & 0.2666 & -0.0963 & \begin{tabular}{|l|}
-0.1969 \\
\end{tabular} & \begin{tabular}{|l|}
-0.1593 \\
\end{tabular} & -0.2447 \\
\hline ME & $\begin{array}{l}-0.0643 \\
\end{array}$ & \begin{tabular}{|l|}
-0.0328 \\
\end{tabular} & \begin{tabular}{|l|}
0.1494 \\
\end{tabular} & \begin{tabular}{|l|}
-0.2907 \\
\end{tabular} & -0.0466 & 0.3287 & \begin{tabular}{|l|}
-0.1407 \\
\end{tabular} & \begin{tabular}{|l|}
-0.1139 \\
\end{tabular} & $\begin{array}{l}-0.1749 \\
\end{array}$ \\
\hline OECD & 0.7230 & -0.0533 & \begin{tabular}{|l|}
-0.1941 \\
\end{tabular} & 0.2918 & -0.0757 & -0.1288 & \begin{tabular}{|l|}
-0.0556 \\
\end{tabular} & \begin{tabular}{|l|}
-0.1171 \\
\end{tabular} & -0.1345 \\
\hline BUDGET & 0.0137 & \begin{tabular}{|l|}
-0.0151 \\
\end{tabular} & \begin{tabular}{|l|}
-0.0379 \\
\end{tabular} & 0.0690 & -0.0213 & -0.0344 & \begin{tabular}{|l|}
-0.0492 \\
\end{tabular} & 0.2733 & -0.0701 \\
\hline DEBT & 0.0668 & \begin{tabular}{|l|}
0.0139 \\
\end{tabular} & -0.2663 & \begin{tabular}{|l|}
0.2741 \\
\end{tabular} & -0.0525 & -0.1754 & \begin{tabular}{|l|}
0.1336 \\
\end{tabular} & \begin{tabular}{|l|}
-0.1697 \\
\end{tabular} & -0.0143 \\
\hline \multirow[t]{2}{*}{ GE } & 0.9528 & \begin{tabular}{|l|}
-0.0764 \\
\end{tabular} & \begin{tabular}{|l|}
-0.2103 \\
\end{tabular} & 0.2683 & -0.1180 & -0.0188 & 0.0604 & \begin{tabular}{|l|}
-0.2063 \\
\end{tabular} & $\begin{array}{l}-0.1298 \\
\end{array}$ \\
\hline & WE & \begin{tabular}{|l|} 
AFRICA \\
\end{tabular} & ME & OECD & BUDGET & DEBT & GE & & \\
\hline WE & 1.000 & & & & & & & & \\
\hline$\overline{\text { AFRICA }}$ & $\begin{array}{l}-0.3702 \\
\end{array}$ & 1.000 & & & & & & & \\
\hline ME & 0.4725 & \begin{tabular}{|l|}
-0.1749 \\
\end{tabular} & 1.000 & & & & & & \\
\hline OECD & 0.4783 & $\begin{array}{l}-0.2840 \\
\end{array}$ & \begin{tabular}{|l|}
-0.2030 \\
\end{tabular} & 1.000 & & & & & \\
\hline BUDGET & $\begin{array}{l}-0.0054 \\
\end{array}$ & -0.0753 & \begin{tabular}{|l|}
-0.0312 \\
\end{tabular} & 0.0201 & 1.000 & & & & \\
\hline DEBT & -0.0544 & 0.1238 & \begin{tabular}{|l|}
-0.0342 \\
\end{tabular} & 0.1169 & 0.0192 & 1.000 & & & \\
\hline GE & 0.4844 & -0.3092 & \begin{tabular}{|l|}
-0.1093 \\
\end{tabular} & 0.7014 & 0.0176 & 0.0363 & 1.000 & & \\
\hline
\end{tabular}

Table 1. Correlation matrix (continuation) 
These findings indicate that the level of technological development of a country, the style of public administration and the control of corruption and government effectiveness are the most significant factors driving the development of e-government.

Moreover, this matrix reveals a lack of high correlations between independent and control variables that can lead to multicollinearity problems. Likewise, the use of the STATA statistical package permit removal of the variables that can cause such problems when running that model.

\subsection{Multivariate analysis results}

The results of the estimation of the dependency Tobit models are shown in Table 2. In the first model, which takes SSI (Emerging) as the dependent variable, only two variables are statistically significant: AGR (negative effect) and GE, for a confidence level of 99 and 90 percent respectively. The remaining proposed variables were statistically non-significant.

Therefore, the simplest model of e-government, based on the mere existence of static web pages with links to different ministries or departments, appeared for those countries whose economies are mainly based on agriculture; their national administrations are oriented toward an improvement of internal management, which leads to a marginal increase in their effectiveness.

The second model, which determined the explanatory factors for SSII (Enhanced), identifies four significant variables: AFRICA and GE, for a confidence level of 99 percent, and CORRU and SERV, for a confidence level of 95 percent. There is a direct relationship between SSII and SERV and GE, while the relationship is the inverse for the variables CORRU and AFRICA. At this stage, the remaining variables do not seem to determine a digital government that is focused on reporting.

Thus, the development of a digital administration based on the disclosure of information, such as reports, laws and regulation, is typical of countries with a services-based economy, in which, even though they have reformed their national administration to increase their effectiveness, they still show major corruption problems. African countries have not evolved to this new stage of e-government. 


\begin{tabular}{|c|c|c|c|c|c|c|}
\hline \multirow[t]{2}{*}{ Dependent variable: } & \multicolumn{2}{|l|}{ SSI } & \multicolumn{2}{|l|}{ SSII } & \multicolumn{2}{|l|}{ SSIII } \\
\hline & Coef. & $\mathbf{t}$ & Coef. & $\mathbf{t}$ & Coef. & $\mathbf{t}$ \\
\hline GDP & $2.11 \mathrm{e}-06$ & 0.32 & $-1.02 \mathrm{e}-06$ & -0.02 & -.0000648 & -1.34 \\
\hline AGRI & 2.458 .847 & 1.32 & -4.679 .288 & -0.37 & 6.011 .197 & 0.45 \\
\hline MAN & .3232023 & 0.29 & 3.684 .855 & 0.48 & -1.421 .909 & -0.18 \\
\hline SERV & -.1879799 & -0.21 & 1.314.819 & $2.14 * *$ & 6.734 .785 & 1.03 \\
\hline AGRISERV & -5.921 .158 & $-3.53 * * *$ & 8.010 .337 & 0.75 & .2797094 & 0.02 \\
\hline MANSERV & -.5018996 & -0.47 & 1.193 .611 & 1.62 & -4.183 .009 & -0.54 \\
\hline ASIA & .882872 & 0.96 & .0476128 & 0.01 & 4.989 .483 & 0.75 \\
\hline $\mathrm{EE}$ & .1447377 & 0.87 & 1.104 .259 & 0.01 & 1.983 .138 & 1.65 \\
\hline AMERICA & .9449615 & 1.28 & 7.807 .785 & 1.55 & 1.282 .352 & $2.40 * *$ \\
\hline WE & .6537765 & 0.80 & -.7451455 & -0.13 & 6.087 .464 & 1.03 \\
\hline AFRICA & -.1438433 & -0.16 & -1.931 .371 & $-3.07 * * *$ & -5.980 .077 & -0.90 \\
\hline $\mathrm{ME}$ & -1.069 .424 & -1.26 & -5.158 .208 & -0.89 & 5.082 .418 & 0.83 \\
\hline $\mathrm{AL}$ & .0079345 & 0.43 & .1965663 & 1.58 & .0105872 & 0.08 \\
\hline IP & -.0086669 & -0.52 & .1299569 & 1.13 & .2741178 & $2.25 * *$ \\
\hline SIZE & $7.48 \mathrm{e}-10$ & 0.58 & $8.75 \mathrm{e}-09$ & 0.99 & $1.02 \mathrm{e}-08$ & 1.10 \\
\hline BUDGET & -1.262 .513 & -0.58 & -8.802 .977 & -0.59 & 8.563 .564 & 0.54 \\
\hline DEBT & -.0027418 & -0.49 & -.0157978 & -0.42 & -.0158063 & -0.40 \\
\hline GE & 1.102 .293 & $1.73 *$ & 1.583.534 & $3.66 * * *$ & $\mathbf{1 . 7 1 7 . 4 5 4}$ & $3.74 * * *$ \\
\hline OECD & -.2113729 & -0.32 & 3.031 .399 & 0.66 & 4.632 .294 & 0.96 \\
\hline CORRU & -.1361352 & -0.47 & -4.156 .907 & $-2.08 * *$ & -319.528 & -1.51 \\
\hline _interc & 6.512.928 & $3.10 * * *$ & 414.319 & $2.92 * * *$ & 4.790 .073 & $3.18 * * *$ \\
\hline Chi-Square & $49.77 * * *$ & & $143.50 * * *$ & & $139.72 * * *$ & \\
\hline Log Likelihood & -232.086 & & -45.751 .923 & & -46.433 .848 & \\
\hline Dependent variable: & SSIV & & SSV & & & \\
\hline & Coef. & $\mathbf{t}$ & Coef. & $\bar{t}$ & & \\
\hline GDP & -.0000299 & -0.75 & -.0000192 & -1.23 & & \\
\hline AGRI & -6.032 .866 & & -2.519 .654 & & & \\
\hline MAN & -1.067 .564 & -1.47 & -2.588 .183 & -0.94 & & \\
\hline SERV & -3.778 .081 & -0.65 & .1048745 & 0.05 & & \\
\hline AGRISERV & 2.693 .578 & 0.28 & -254.466 & & & \\
\hline MANSERV & -2.948 .854 & -0.43 & -1.090 .055 & -0.41 & & \\
\hline ASIA & .2444157 & 0.04 & .7587087 & 0.34 & & \\
\hline $\mathrm{EE}$ & -5.989 .529 & & .7065227 & 0.17 & & \\
\hline AMERICA & 6.547 .716 & 1.40 & 3.203 .765 & $1.81 *$ & & \\
\hline WE & -5.027 .812 & -0.99 & -214.443 & -1.10 & & \\
\hline AFRICA & -4.652 .984 & -0.76 & -1.281 .352 & -0.56 & & \\
\hline $\mathrm{ME}$ & 159.981 & $3.10 * * *$ & 4.790 .764 & $2.40 * * *$ & & \\
\hline $\mathrm{AL}$ & -.060619 & -0.52 & .0042977 & 0.09 & & \\
\hline IP & .0347622 & 0.34 & .0643329 & 1.63 & & \\
\hline SIZE & $1.15 \mathrm{e}-08$ & 1.46 & $3.08 \mathrm{e}-09$ & 1.02 & & \\
\hline BUDGET & 1.011 .265 & 0.77 & 2.336 .914 & 0.46 & & \\
\hline DEBT & -.020027 & -0.55 & -.013399 & -0.98 & & \\
\hline GE & 9.891.807 & $2.33 * *$ & 2.992.422 & $1.90 *$ & & \\
\hline OECD & 8.769 .466 & $2.16 * *$ & 3.785.305 & $2.42 * * *$ & & \\
\hline CORRU & .9770351 & 0.52 & -.3196759 & -0.46 & & \\
\hline _interc & 113.451 & 0.83 & 3.723 .114 & 0.71 & & \\
\hline Chi-Square & $112.40 * * *$ & & 93.38*** & & & \\
\hline Log Likelihood & -36.407 .998 & & -28.806 .911 & & & \\
\hline
\end{tabular}

Table 2. Tobit regression results

The estimation of the third model, with the dependent variable SSIII (Interactive), led to three significant variables, with all of which showed a positive effect: IP, AMERICA and GE, for a confidence level of 95 percent for the two 
first variables and 99 percent for the last one. Therefore, the countries that have evolved to an interactive system, which is focused on the opportunity to make tax payments and apply for license renewals, are concentrated on the American continent and show a high level of both technological development as well as a very effective national administration.

In model 4, with dependent variable SSIV (Transactional), the variables ME, OECD and GE are statistically significant, with a positive effect, for a confidence level of 99 percent (ME) and 95 percent (OECD, GE).

The development of an interactive system towards the transactional system, which allows for two-way interactions between citizens and governments and for which all transactions are conducted on-line, is characteristic of countries from the Middle East regions as well as those countries from the OECD; all of these countries show a national administration that is assessed highly in efficacy levels by their citizens.

Finally, model 5, which explained the most sophisticated level of e-government (SSV-Connected), indicated the variables AMERICA, ME, OECD and GE as explanatory factors behind this level of e-government. All of these variables show a direct relationship with the dependent variable, for confidence levels ranging from 95 percent to 99 percent.

The most developed typology of e-government is typical of North America and Middle Eastern countries, as well as those from the OECD. As a prerequisite, they again show a national administration with a particularly effective internal management.

Table 3 shows a summary of the significant variables for the models and the hypotheses they refer to, illustrating the approval or rejection of our proposed hypotheses. Based on this table and given that the variable GE turns out to be statistically significant for all of the models estimated, hypothesis H7, which refers to the relationship between government effectiveness and the development of e-government, was accepted with the proposed sign. Moreover, hypothesis H8 was accepted as well. Those countries that have developed an administration style based on reforms that seek efficiency and quality in public management, as encouraged by the OECD, exhibit the most complex and developed levels of 
electronic administration, that is, Services Stages IV (Transactional) and V (Connected).

\begin{tabular}{|c|c|c|c|c|c|c|c|}
\hline \multirow[b]{2}{*}{ Variables } & \multirow[b]{2}{*}{ Hypotheses } & \multirow[b]{2}{*}{ Expected sign } & \multicolumn{5}{|c|}{ Obtained sign } \\
\hline & & & $\begin{array}{c}\text { SSI } \\
\text { (Emerging) }\end{array}$ & $\begin{array}{c}\text { SSII } \\
\text { (Enhanced) }\end{array}$ & $\begin{array}{c}\text { SSIII } \\
\text { (Interactive) }\end{array}$ & $\begin{array}{c}\text { SSIV } \\
\text { (Transactional) }\end{array}$ & $\begin{array}{c}\text { SSV } \\
\text { (Connected) }\end{array}$ \\
\hline AGRI & & & - & & & & \\
\hline SERV & & & & + & & & \\
\hline AFRICA & H1 & + & & - & & & \\
\hline AMERICA & & $\begin{array}{c}\text { (some } \\
\text { variables may } \\
\text { have negative } \\
\text { effects) }\end{array}$ & & & + & & + \\
\hline ME & & & & & & + & + \\
\hline IP & $\mathrm{H} 2$ & + & & & + & & \\
\hline GE & $\mathrm{H} 7$ & + & + & + & + & + & + \\
\hline OECD & $\mathrm{H} 8$ & + & & & & + & + \\
\hline CORRU & H9 & + & & - & & & \\
\hline
\end{tabular}

Table 3. Relationships between the findings and the proposed hypotheses

Hypotheses $\mathrm{H} 1$ and $\mathrm{H} 2$ required a more complex reasoning for their verification. Concerning hypothesis $\mathrm{H} 1$, the main variable proposed to test it, GDP, was not significant; however, the activity sector on which the economy of the countries is based and the geographic continent that can define its level of development do significantly influence the development and improvement of digital administration. Consequently, hypothesis $\mathrm{H} 1$ was mostly verified.

Hypothesis H2 was also accepted. Although a specific influence on the improvement of e-government was detected, this influence was not worthless because such an effect is essential in the transformation of Internet usage. More specifically, the spread of Internet usage involves a previous requirement so that the national administration can begin defining an interactive electronic system, allowing the simplest transactions to be conducted online.

Regarding hypothesis $\mathrm{H} 9$, the results for the variable CORRU only allow partial acceptance, which is the opposite effect of that expected. The reason for this result is because only national administrations with lower levels of egovernment development (focused on reporting to citizens) correspond to the countries that exhibit greater corruption problems. No evidence was obtained that the government becomes more transparent and participatory online as more ethical behaviors are achieved.

The remaining hypotheses were rejected given the absence of statistical significance of the variables proposed for their empirical study. 


\section{DISCUSSION}

Our findings concerning the influence of socioeconomic and demographic factors on the development of e-government allowed us to affirm that a higher level of improvement in e-government is strongly linked to countries that have both a services-based economy (as opposed to the agriculture sector) and a high evel of technological development.

Concerning technological development, our results are in accordance with those of Pina et al. (2007b) for European regions and towns but differ from the negative impact detected by Tolbert et al. (2008) and from the non-significant impact obtained by Pina et al. (2007a), Kim (2007) and Gandía and Archidona (2008). This divergence of results may be explained by the typology of egovernment analyzed and by the study context. While this study analyzed a diversified sample, other works have focused on municipalities or states within the same geographical context. This approach usually illustrates a similar evolution in Internet usage as a consequence of a national policy that favors its development.

Unlike previous studies (Kim, 2007; Tolbert et al., 2008), we did not obtain evidence of a close relationship between the economic wealth of a country and citizens' education and the development of digital government. On the contrary, we found that the typology of economic development that is typical of the Middle East and of the North American continent positively influences the improvement of the electronic administration and its evolution toward a citizen-administration relationship developed through the Internet.

As for the internal features of the public body, in accordance with Kim (2007), we found that administrative effectiveness is a necessary prerequisite for the development of e-government. This finding is not surprising, as it may be expected that the administrations with effective management tend to increase the processes of transparency in their activities and their interaction with citizens; this situation is difficult to find in administrations with more chaotic management situations.

With regard to the style of public administration, several works (e.g., Rodríguez et al., 2005; Pina et al., 2007a) have studied the relationship between a citizen-oriented administrative culture and the use of websites as tools for 
reporting in European municipalities (similar to the II Services Stage Enhanced).

Our findings allowed us to generalize the effect of administrative culture on the development of an e-government that is more connected with its citizens, in which all services are available on the Internet, which permits a wide range of transactions to be conducted on the Internet and fosters the participation of citizens in public management through this new communication channel.

Consistent with Pina et al. (2007b) but not with Kim (2007), it is apparent that the level of control of corruption in a country does not encourage the development of digital government. On the contrary, we detected that those countries with higher problems of political and administrative corruption use the national administrations' websites as mechanisms for making amends for their activities, by disclosing annual reports, laws and regulations.

Nonetheless, in contrast to Pina et al. (2007a) and Gandía and Archidona (2008), the organizational complexity of the public body lacks statistically significant relevance. These differences may stem from the administration context analyzed in the different studies. While previous works have usually focused on local administrations, our study focuses on national administrations.

Moreover, according to previous evidence for Spanish municipalities (Gandía and Archidona, 2008), a significant relationship was not found between leverage and institutional capacity and the level of development of public websites of the national administration.

\section{CONCLUSIONS}

The advantages in frequency and timeliness, as well as the decrease in information distribution costs, have made the Internet an indispensable communication channel in the relationship between public administrations and their users / citizens. The development of e-government may constitute an important opportunity to improve the informative and relational capacity of websites, as well as to contribute to public management transparency.

According to several U.N. reports, the development of public administration websites can show five different stages, which are organized by the increasing complexity of the citizen-administration relationship. 
This work has focused on determining the explanatory factors in the level of improvement and development of the national administrations' websites from 192 countries, based on a 2008 United Nations report.

Our findings emphasize that the internal effectiveness of the public body, as well as a style of public management that is oriented toward economy, efficiency and transparency - although not necessarily towards ethics - is a basic condition in the implementation and development of e-government. It is worth noting the accumulative character of administrative effectiveness, which is present in all the development levels of digital government. The effectiveness achieved previously by public administrations significantly empowers the development of the digital government. The performance of a digital government cannot be separated from the general ability of the administration, including the fulfillment of programs and public policies efficiently, effectively and responsibly. The competence of civil servants, the ease of use of governmental websites and their rapid response to citizens' demands are necessary to achieve a high level of development and performance in electronic government.

However, developing an electronic administration to permit a higher level of interaction online is more commonly linked to the economic development styles that are typical of the North American continent and the Middle East, rather than the standard of living or citizens' education. The spread of Internet usage is considered to be a key factor in the evolution of e-government from static websites to a dynamic e-government.

Finally, a political use of the Internet is detected for countries with lower ethical levels, that is, a higher degree of corruption, perhaps as a way to solve corruption problems through an increase in the disclosure of information online or perhaps as an electoral mechanism that attempts to mask the true ethical situation of the primary political and administrative bodies in those countries.

In this sense, further studies should be undertaken to determine the true purposes of politicians and managers concerning the development of egovernment. Inter- and intra-country comparisons would be essential in the service of that goal. Likewise, it would be beneficial to contrast the relationships observed by this paper with other contexts of public administrations, i.e., local, national and regional, in order to generalize the results found here. 


\section{REFERENCES}

ALLEN, B.; JUILlET, L.; PAQUET, G.; ROY, J. (2001), "E-governance \& government on-line in Canada: Partnerships, people \& prospects", Government Information Quarterly, vol. 18, n. 2: 93-104. http://dx.doi.org/10.1016/S0740$\underline{624 X(01) 00063-6}$

BABER, W.R.; SEN, P.K. (1984), “The role of generally accepted reporting methods in the public sector: An empirical test", Journal of Accounting \& Public Policy, vol. 3, n. 2: 91-106. http://dx.doi.org/10.1016/0278-4254(84)90002-4

BANKER, R.D.; PATTON, J.M. (1987), "Analytical agency theory and municipal accounting: An introduction and an application", Research in Governmental and Non Profit Accounting, vol. 3: 29-50.

CABA, C.; RODRÍGUEZ, M.P.; LÓPEZ, A.M. (2008), "e-Government process and incentives for online public financial information", Online Information Review, vol. 32, n. 3: 379-400. http://dx.doi.org/10.1108/14684520810889682

CABA, C.; LÓPEZ, A.M.; RODRÍGUEZ, M.P. (2005), “Citizens” access to online governmental financial information: Practices in the European Union Countries", Government Information Quarterly, vol. 22, n.2: 258-276. http://dx.doi.org/10.1016/j.giq.2005.02.002

CÁRCABA, A.; GARCÍA, J. (2008), "Determinantes de la divulgación de información contable a través de Internet por parte de los gobiernos locales", Revista Española de Financiación y Contabilidad, vol. 137: 63-84.

CHRISTOU, G; SIMPSON, S. (2009): "New Governance, the Internet, and Country Code Top-Level Domains in Europe", Governance: An International Journal of Policy, Administration and Institutions, vol. 22, n. 4: 599-624.

CHRISTIANES, J. (1999), "Financial accounting reform in Flemish municipalities: An empirical investigation", Financial Accountability \& Management, vol. 15, n. 1: 21-40. http://dx.doi.org/10.1111/1468-0408.00072

EVANS, J.H.; PATTON, J.M. (1987): "Signaling and monitoring in public sector accounting", Journal of Accounting Research, vol. 25: 130-158. http://dx.doi.org/ $\underline{10.2307 / 2491083}$ 
GANDÍA J.L.; ARCHIDONA, M.C. (2008), "Determinants of web site information by Spanish city councils", Online Information Review, vol. 32, n.1: 35-57. http://dx.doi.org/10.1108/14684520810865976

INGRAM, R.W.; DEJONG, D.V. (1987), "The effect of regulation on local government disclosure practices", Journal of Accounting \& Public Policy, vol. 6 n. 4: 245-270. http://dx.doi.org/10.1016/S0278-4254(87)80002-9

INGRAM, R.W. (1984), "Economic incentives and the choice of state government accounting practices", Journal of Accounting Research, vol. 22, n.1: 126-144. http://dx.doi.org/10.2307/2490704

JUSTICE, J.B.; MELITSKI, J. SMITH, D.L. (2006), "E-Government as an instrument of fiscal accountability and responsiveness: Do the best practitioners employ the best practices?", American Review of Public Administration, vol. 36, n.3: 301-322. http://dx.doi.org/10.1177/0275074005283797

KAUFMAN, D.; KRAAY, A. Mastruzzi, M. (2008), “Governance matters III: Governance indicators for 1996-2007”, World Bank, Available online at http://www.worldbank.org

KAUFMAN, D.; KRAAY, A. Mastruzzi, M. (2003), "Governance matters III: Governance indicators for 1996-2002", World Bank, Available online at http://www.worldbank.org

KIM, Ch.K. (2007), “A cross-national analysis of global E-government”, Public Organization Review, vol.7: 317-329. http://dx.doi.org/10.1007/s11115-007-0040-5

LASWAD, F.; FISHER, R. OYELERE, P. (2005), "Determinants of voluntary Internet financial reporting by local government authorities", Journal of Accounting and Public Policy, vol. 24: 101-121. http://dx.doi.org/10.1016/j.jaccp ubpol.2004.12.006

LEE, J. (2010), "10 years retrospect on stage models on e-Government: A qualitative meta-synthesis", Government Information Quarterly, vol. 27, n.3: 220230. http://dx.doi.org/10.1016/j.giq.2009.12.009

MCNEAL, R.S.; TOLBERT, C.J.; MOSSBERGER, K.; DOTTERWEICH, L.J. (2003), "Innovating in digital government in the American States", Social Science Quarterly, vol. 84, n.1: 52-70. http://dx.doi.org/10.1111/1540-6237.00140 
MOON, M.J. (2002), "The evolution of E-government among municipalities: Rhetoric or reality?", Public Administration Review, vol. 62, n.4: 424-433. http://dx.doi.org/10.1111/0033-3352.00196

MOSSBERGER, K.; TOLBERT, C.J.; GILBERT, M. (2004), "Race, place and information technology", Paper presented at the annual meeting of the American Political Science Association, September 2-5, 2004, Chicago, IL.

PINA, V.; TORRES, L. ROYO, S. (2007a), “Are ICTs improving transparency and accountability in the EU regional and local governments?: An empirical study", Public Administration, vol. 85, n.2: 449-472. http://dx.doi.org/10.1111/j.1 467-9299.2007.00654.x

PINA, V.; TORRES, L. ROYO, S. (2007b), "Is E-government leading global convergence towards accountable governments?", XIV Congreso de AECA, 1921 Septiembre, Valencia (Spain).

RODRÍGUEZ, M.P.; CABA, C.; LÓPEZ, A.M. (2005), "Cultural contexts and governmental digital reporting", International Review of Administrative Sciences, vol. 72, n.2: 269-290.

SERRANO-CINCA, C.; RUEDA-TOMÁS, M.; PORTILLO-TARRAGONA, P. (2009), "Factors influencing e-disclosure in local public administrations", Environment and Planning C: Government and Policy, vol. 27, n.2: 355-378. http://dx.doi.org/10.1068/c07116r

SIAU, K.; LONG, Y. (2006), "Using social development lenses to understand Egovernment development", Journal of Global Information Management, vol. 14, n.1: 47-62. http://dx.doi.org/10.4018/jgim.2006010103

SPRECHER, M. (2000), "Racing to e-government: Using the Internet for citizen service delivery", Government Finance Review, vol. 16, n.5: 21.

TOLBERT, C.J.; MOSSBERGER, K.; MCNEAL, R. (2008), "Institutions, policy and E-government in the American States", Public Administration Review, vol. 68, n. 3: 549-563. http://dx.doi.org/10.1111/j.1540-6210.2008.00890.x

TOLBERT, C.J.; MOSSBERGER, K. (2006), "The effects of E-government on trust and confidence in government", Public Administration Review, vol. 66, n. 3: 354-369. http://dx.doi.org/10.1111/j.1540-6210.2006.00594.x 
TORRES, L.; PINA, V.; ACERETE, B. (2006): "E-governance developments in European Union cities: Reshaping government's relationship with citizens", Governance: An International Journal of Policy, Administration, and Institutions, vol. 19, n.2: 277-302.

TORRES, L.; PINA, V.; ROYO, S. (2005), "E-government and the transformation of public administrations in EU countries: Beyond NPM or just a second wave of reforms?", Online Information Review, vol. 29, n.5: 531-553. http://dx.doi.org/10.1108/14684520510628918

WEST, D. (2004), "E-government and the transformation of service delivery and citizen attitudes", Public Administration Review, vol. 64, n. 1: 15-27. http://dx.doi.org/10.1111/j.1540-6210.2004.00343.x

WEST, D. (2003), "State and federal E-government in the United States 2003", Available at http://www.insidepolitics.org/policyreports.html

WEST, D. (2002), "State and federal E-government in the United States 2002", Available at http://www.insidepolitics.org/policyreports.html

WEST, D. (2001), "State and federal E-government in the United States 2001", Available at http://www.insidepolitics.org/policyreports.html

WEST, D. (2000), "State and federal E-government in the United States 2000", Available at http://www.insidepolitics.org/policyreports.html

WONG, W.; WELCH, E. (2004), "Does E-government Promote Accountability? A Comparative Analysis of Website Openness and Government Accountability", Governance: An International Journal of Policy, Administration and Institutions, vol. 17, n.2: 275-297.

ZIMMERMAN, J.L. (1977), “The municipal accounting maze: An analysis of political incentives", Journal of Accounting Research, vol. 15: 107-44. http://dx.d oi.org/10.2307/2490636 